\title{
Nanoparticles in the Lung and their Protein Corona: The Few Proteins that Count
}

Harry Whitwell ${ }^{1}$, Rose-Marie Mackay ${ }^{1}$, Christine Elgy ${ }^{2}$, Cliff Morgan ${ }^{3}$, Mark Griffiths ${ }^{3}$, Howard Clark $^{1,4,5}$, Paul Skipp ${ }^{4,5^{*}}$, and Jens Madsen ${ }^{1,4,5^{*}}$

1 Child Health, Clinical and Experimental Sciences, Faculty of Medicine, University of Southampton, Southampton General Hospital, Southampton SO16 6YD, United Kingdom.

2 School of Geography, Earth and Environmental Sciences, University of Birmingham, Birmingham, B15 2TT, United Kingdom.

3 Leukocyte Biology, Royal Brompton Campus, Imperial College London, London, SW3 6NP, United Kingdom.

$4 \quad$ Institute for Life Sciences, University of Southampton, Southampton, SO17 1BJ, United Kingdom.

5 National Institute for Health Research, Southampton Respiratory Biomedical Research Unit, Southampton Centre for Biomedical Research, University Hospital Southampton NHS Foundation Trust, Southampton, SO16 6YD, United Kingdom.

*These authors contributed equally to the manuscript.

Keywords: Nanoparticles, surfactant, lung, corona, surface chemistry

Address for correspondence:

Jens Madsen PhD

Child Health,

Sir Henry Wellcome Laboratories

Clinical and Experimental Sciences,

Faculty of Medicine,

University of Southampton,

Southampton General Hospital,

Tremona Road,

Southampton

SO16 6YD.

United Kingdom.

Phone: +442380794940

Email: j.madsen@southampton.ac.uk 


\begin{abstract}
The formation of protein coronas on nanoparticles (NP) has been investigated almost exclusively in serum, despite the prevailing route of exposure being inhalation of airborne particles. In addition, an increasing number of nanomedicines, that exploit the airways as the site of delivery, are undergoing medical trials. An understanding of the effects of NPs on the airways is therefore required. To further this field, we have described the corona formed on polystyrene particles with different surface modifications and on titanium dioxide particles when incubated in human bronchoalveolar lavage fluid (BALF) from patients with protein alveolar proteinosis (PAP). We show, using highresolution quantitative mass spectrometry $\left(\mathrm{MS}^{\mathrm{E}}\right)$, that a large number of proteins bind with low copy numbers but that a few 'core' proteins bind to all particles tested with high fidelity, averaging the surface properties of the different particles independent of the surface properties of the specific particle. The averaging effect at the particle surface means that differing cellular effects may not be due to the protein corona but due to the surface properties of the nanoparticle once inside the cell. Finally, the adherence of surfactant associated proteins (SP-A, B and D) suggests that there may be interactions with lipids and pulmonary surfactant (PSf), which could have potential in vivo health effects for people with chronic airway diseases such as asthma and chronic pulmonary obstructive disease (COPD), who have increased susceptibility toward other respiratory diseases.
\end{abstract}




\section{Introduction}

Epidemiological studies have demonstrated a link between airborne particulate matter and increased morbidity and mortality (Laden et al. 2000; Laden et al. 2006; Pope et al. 2004; Samet et al. 2000). In light of this and increased usage of nanoparticles (NPs) in modern composite materials, including application of nano-sized therapeutics (Schütz et al. 2013), numerous studies are aimed at understanding the fate and cellular toxicity of nanoparticles (NPs $<100 \mathrm{~nm}$ ) (Commission 2011). Inhaled NPs may reach the lower lung alveolus (Oberdörster et al. 2005) where the particles can interact with pulmonary surfactant (PSf) (Schleh \& Hohlfeld 2009), a single molecule layer of predominantly (90\%) phospholipids and proteins (10\%) (Pérez-Gil 2008), before passing into the underlying hydrophase. In biological media, NPs rapidly become coated in proteins, which form a corona around their surface (Cedervall et al. 2007) and thus previously biologically inert particles may acquire a biological identity.

Surfactant associated proteins and lipids can bind to NPs (Kendall et al. 2012; McKenzie et al. 2015; Kendall 2007; Ruge et al. 2012). Therefore, there is potential for NPs to have an in vivo effect on surfactant function. This is further evidenced through in silico modelling of surfactant function and NP translocation through the surfactant monolayer (Hu et al. 2013; Choe et al. 2008). Metallic NPs may reduce the surface activity of model surfactant (Bakshi et al. 2008), through mechanisms likely to be associated with adsorption of PSf components such as proteins (Fan et al. 2011; Dwivedi et al. 2014).

To date, many studies have investigated NP-protein interactions in serum, for which comprehensive lists of proteins that adsorb to the NP corona have been published (Tenzer et al. 2013; Cedervall et al. 2007; Schäffler et al. 2013) and it may be possible to predict the cellular fate of NPs from this data (Walkey et al. 2014). However, there remains no analysis or identification of proteins bound to NPs in the context of the lung. This is likely due to the abundant and convenient availability of serum compared with a lung-related bio-fluid, for nanoparticle-protein kinetic studies.

Patients with pulmonary alveolar proteinosis (PAP) (Seymour \& Presneill 2002) have reduced recycling and consequent build-up of PSf within their alveoli. The lipo-proteinaceous material may be removed through whole lung lavage which is typically performed during a single procedure, and can result in approximately 12-15 L of material per patient (Strong et al. 1998; Shah 2000). This material differs from 'healthy' lung through increased levels of lipids and surfactant protein A (SP-A) (Honda 1993) and SP-D (Honda et al. 1995) with a 10-fold and 7-fold increase respectively. The proportion of SP-A to the total protein is similar between PAP and healthy control, suggesting that whilst the fluid may be more concentrated for lipids and proteins, the proportions of these proteins remains constant (Honda 1993). Therefore, we believed that this media would be a useful source of pulmonary material for investigating NP-protein interactions within the context of the pulmonary system.

Using high resolution, quantitative mass spectrometry $\left(\mathrm{MS}^{\mathrm{E}}\right)$, we describe the proteins from BALF binding to 3 polystyrene (PS) NPs with different surface modifications - aminated (aPS), carboxylated (cPS) and unmodified (UPS) - and one metal $\left(\mathrm{TiO}_{2}\right)$ and a time study of the corona formed around aPS and cPS. The research has demonstrated that only a few proteins bind to the NPS with high fidelity and do so regardless of particle surface functionality. Furthermore, we have observed the adherence of surfactant associated proteins (SP-A, SP-B and SP-D) binding to the surface of the particles, suggesting a mechanisms through which inhaled NPs may affect health. 


\section{Methods}

For full method descriptions, see Supplementary Methods.

Nanoparticles

$100 \mathrm{~nm}$ polystyrene (PS) were purchased from Polysciences Incorporated (Germany) and $\mathrm{TiO}_{2}$ particles from Evonik Industries (UK). Particles were stored at $4^{\circ} \mathrm{C}$ and were handled in a class 2 safety cabinet to maintain their sterility.

\section{Dynamic Light Scattering and Zeta Potential}

Hydrodynamic diameter and zeta potential (ZP) measurements were acquired at $37^{\circ} \mathrm{C} .5 \mathrm{~cm}^{2}$ of nanoparticles were suspended in $1 \mathrm{~mL}$ of PBS. We were not able to take comparable measurements in BALF due to health and safety concerns about the risk of contamination of the apparatus from unscreened human material.

\section{Cell Culture and Cellular Assay}

A549 cells were treated with BALF-coated or untreated NPs for 24 hours. Mitochondrial activity was assessed by the cells ability to reduce MTT to insoluble formazan, the concentration of which was determined by absorbance at $550 \mathrm{~nm}$.

\section{Bronchoalveolar Lavage Fluid and Corona Formation}

Bronchoalveolar lavage fluid (BALF) was acquired by therapeutic lung lavage from a patient suffering pulmonary alveolar proteinosis (PAP) with informed consent under approved ethics (NRES reference 10/H0504/9). Approximately $13 \mathrm{~L}$ was acquired from a single patient and the first $4 \mathrm{~L}$ were pooled and aliquoted prior to freezing at $-20^{\circ} \mathrm{C}$. Before incubating the particles, the BALF was defrosted and briefly centrifuged at low speed to pellet large agglomerates and cellular debris before being centrifuged for 30 minutes at $10,000 \times \mathrm{g}$ to remove smaller agglomerates.

For LC-MS analysis of the proteins corona, $50 \mathrm{~cm}^{2}$ of particles were incubated in $20 \mathrm{~mL}$ (approximately $5 \mathrm{mg}$ total protein) of BALF for $15,30,60$ or 120 minutes. For cellular assays, $500 \mathrm{~cm}^{2}$ of particles were suspended in $30 \mathrm{~mL}$ of BALF for 60 minutes. Particle-BALF mixtures were centrifuged at $10,000 \times \mathrm{g}$ for 30 minutes to pellet the NPs, which were either washed 5 times with 1 $\mathrm{mL}$ phosphate buffered saline, centrifuging for 15 minutes at $17,000 \times \mathrm{g}$ (for corona analysis) or diluted to relevant concentrations by serial dilution in serum-free media for cellular assays.

LC-MS

Particles were run into an SDS PAGE gel for 10 minutes to elute the proteins. Each lane was then excised and cut into approximately $1 \mathrm{~mm}^{3}$ pieces and in gel reduction, alkylation and tryptic digestion performed. Peptides were extracted using $1 \%(\mathrm{v} / \mathrm{v})$ formic acid, and $2 \%(\mathrm{v} / \mathrm{v})$ acetonitrile in $25 \mathrm{mM}$ ammonium bicarbonate buffer. Samples were analysed by LC-MS ${ }^{\mathrm{E}}$ in resolution mode (Acuity UPLC M-Class, Synapt G2S, Waters) over a 30 minutes gradient of acidified ( $0.1 \% \mathrm{v} / \mathrm{v}$ formic acid) acetonitrile (3-40\%).

Protein Identification, Bioinfomatics and Statistics

Database searching and quantification was performed in ProteinLynx Global Server version 3.0 (Waters), searching against human SwissProt (UniProt). Protein characteristics were extracted from ProtParam (ExPAsy). 


\section{Results}

\section{Particle Characterisation}

Nanoparticles were thoroughly characterised by dynamic light scattering, electron microscopy and atomic force microscopy. Since agglomerated particles were not monodispersed, as is assumed by DLS, we have reported their size by 'number' (for z-averages, see supplementary table ST1). All particles increased in size following incubation in BALF. Both aPS and $\mathrm{TiO}_{2}$ particles formed large agglomerates in BALF (approximately $90 \%$ and $439 \%$ increase in size, respectively, by TEM), whereas CPS and uPS were more stable (supplementary table ST2). Since size was variable depending on method used to measure them and their suspension media, we used $100 \mathrm{~nm}$ (manufacturers label size) for surface area calculations of the polystyrene and $14.09 \mathrm{~nm}$ for $\mathrm{TiO}_{2}$. For all particles, zeta potential was negative, with aPS least negative, followed by uPS, CPS and $\mathrm{TiO}_{2}$ ($11.5 \mathrm{mV},-17.07,-19.73$ and $-22.7 \mathrm{mV}$ respectively) in PBS ( $\mathrm{pH}$ 7.4). Owing to the agglomeration of aPS and $\mathrm{TiO}_{2}$ in $\mathrm{BALF}$, we incubated the particles in large volumes $(20-30 \mathrm{~mL})$ of BALF to minimise the agglomeration.

Particle toxicity was determined following cellular exposure to BALF-incubated or non-incubated particles at a range of concentrations for 24 hours (Figure 1). Both BALF coated and uncoated aPS particles decreased the reduction of MTT in living cells when added at high concentrations. Uncoated particles caused a statistically significant decrease by $100 \mathrm{~cm}^{2} / \mathrm{mL}$ whereas uncoated particle did not reach significant levels (Figure 1A). The addition of uncoated cPS particles caused a large increase in absorbance, whereas coated particles caused no deviation from untreated cells (Figure 1B). Uncoated uPS particles also caused a statistical increase, whereas there was no change when the particles had been pre-incubated in BALF (Figure $1 \mathrm{C}$ ). In contrast, $\mathrm{TiO}_{2}$ particles caused no effect when uncoated, however, BALF-incubated particles caused an increase at concentrations of 1 $\mathrm{cm}^{2} / \mathrm{mL}$ and below. It was observed that at low concentrations $\left(0.01-1 \mathrm{~cm}^{2} / \mathrm{mL}\right)$, there was an increase in mitochondrial activity as observed by higher levels of insoluble fomazan. Preliminary experiments were performed showing no effect of the particles on MTT reduction, nor any effect of BALF at $1 \%(v / v)$ concentration (data not shown).

Bronchoalveolar Lavage Fluid

The protein concentration of BALF was determined after a freeze thaw cycle and after centrifugation at $10,000 \times \mathrm{g}$ for 30 minutes to be approximately $251 \mu \mathrm{g} / \mathrm{mL}$. After the same treatment, phospholipid content was determined to be below the detectable range of the assay $(<10 \mu \mathrm{g} / \mathrm{mL}$ ).

\section{Protein Corona}

As different modifications can lead to different cellular effects, we wished to determine if this was also true for the proteins that bound to the surface of the particles. We determined, by SDS PAGE and BSA assay, that 5 washes were sufficient to remove non-bound proteins (Supplementary figure S1).

Corona proteins from both aPS and cPS particles, incubated for 15, 30, 60 or 120 minutes were identified and quantified to gain an insight into the dynamics of protein-particle interactions on a time scale relevant in vivo (Supplementary File SF1 and SF2). The corona of $\mathrm{TiO}_{2}$ and uPS particles were also analysed after 60 minutes incubation in BALF (SF3). Proteins were normalised by dividing each sample by the sum of proteins ( $\mathrm{fmol}$ ) present in at least $90 \%$ of all samples and identifications were accepted if they were detected in at least two repeats of a single time point (i.e. a subsequent identification of a bound protein in only 1 repeat was allowed provided at a different time point it 
was detected in at least 2 repeats). Quantifications were only accepted if they were present in at least 2 repeats for each individual time points.

The number of particles per molecule (calculated by dividing the number of molecules (mols*Avogadro's number) by the number of particles) were consistant for cPS particles over the time course analysed, with an average of 400 protein molecules per particle (supplementary figure S2A). The number of molecules per particle for aPS averaged at 517, but, unlike cPS, was not a constant value, peaking at 30 minutes before dropping at 60 and 120 minutes. There was, however, large variation at 30 and 60 minutes, suggesting that the evolution of the corona may be changeable. When incubated for 60 minutes, carboxylated particles bound statistically fewer molecules than aPS or uPS ( $\mathrm{P}=0.006$ and 0.042 , respectively), $\mathrm{TiO}_{2}$ bound more molecules, although not statistically so (supplementary figure S2B). Aminated and carboxylated polystyrene particles and $\mathrm{TiO}_{2}$ particles bound similar numbers of molecules (aprox. 700 ) despite there being orders of magnitude difference in their sizes.

The protiens binding to aPS and cPS particles were investigated over time. There were 34 and 32 proteins detected that were common to all time points for aPS and CPS respectively (Figure 2), however, over time, both changed, with unique proteins being detected at all time points for aPS particles and at 30 minutes and 120 minutes for cPS particles. Of the proteins shared at all time points, 16 were quantified for aPS and cPS. These proteins changed very little over time and in general were present in high abundance on the particles (Figure $\mathbf{2 C}$ and $\mathrm{D}$ ).

To determine if the proteins were binding in a concentration-dependant manner - i.e. if the most abundant proteins in BALF were the most abundant proteins bound to the particles, BALF was also analysed by LC-MS ${ }^{\mathrm{E}}$ (SF4). The distribution of BALF proteins identified were ordered by their abundance, with the overall top 20 proteins found bound to the particles highlighted in red (Figure 3). This showed that the most abundant proteins in the corona were not necessarily the most abundant in BALF and this was the case for all particles. Furthermore, there was high conservation of the corona at each time point for aPS and cPS (Figure 3A and B). Not all the proteins detected on the particles were identified in BALF, showing that proteins present in low amounts in bodily fluids can become concentrated on the particles. This suggests that there might be a physiochemical feature of the proteins driving their adhesion to the particles and vice versa.

We investigated various properties of the bound proteins bioinfomatically, weighting by their abundance (Figure 4). The bound proteins were, in general, small ( $<80 \mathrm{kDa})$, hydrophilic and acidic with little change in the average characteristics over the time course or between particles, although aPS particles bound proteins with a slightly higher GRAVY score (hydophobic). Principle Component Analysis (PCA) analysis of the unique proteins bound to each particle at 60 minutes was not able to discriminate between the particles based on their physical characteristics (data not shown).

It was evident that the protein corona is relatively dynamic over time and cluster analysis grouping proteins by binding-pattern, identifying four distinct groups for aPS (Figure 5A) and cPS (Figure 5C).

The physiochemical properties of the bound proteins were plotted using a PCA analysis which was then coloured according to the cluster the protein conformed to. This analysis did not highlight any relationship between their biophysical characteristics and their binding moiety.

There were differences in the identity of the bound proteins between aPS and cPS over time (Figure $\mathbf{2 A}$ and $\mathrm{B}$ ) and all particles (SF1, $\mathbf{2}$ and $\mathbf{3}$ ) that was not reflected in the bioinfomatic data. This could be due to skewing by the abundant proteins. On average, less than $1 \%$ of the bound protein at any time point accounts for $20 \%$ of the total proteins present, and $20 \%$ of the bound proteins account 
for $60 \%$ of the total protein corona (Figure 6). Over time, the distribution of proteins bound to aPS particles changed very little, whereas for cPS particles, after 60 minutes, the proportion of protiens changed such that the percetage of proteins responsible for $80 \%$ of the total bound protein increased from $50 \%$ to $60 \%$. Furthermore, there is strong conservation between the top 5-10 proteins bound to aPS (Table 2) and cPS (Table $\mathbf{3}$ ) over time as well as to all particles (Table 1). 


\section{Discussion}

Zeta potential readings of these particles were all less than $0 \mathrm{mV}$. Even for aPS particles that carry a positively charged functional group, the overall charge was negative, suggesting a low concentration of surface groups. Since the zeta potential of all the particles was quite close, any differences observed in the protein corona between PS particles are probably not a consequence of surface charge, but due to the functional groups.

We identified a number of intracellular proteins from BALF which we would not expect to be present in a healthy lung and may be a result of mechanical agitation of lung tissue whilst acquiring the lavage. The presence of serum proteins suggests some degree of leakage into the lung from the underlying vasculature which it is likely also a common in vivo occurrence (Ward et al. 1997), although may also be exacerbated by mechanical agitation.

Lactose dehydrogenase (LDH) and MTT assays are commonly performed to assay the toxicity of NPs. It has been observed by ourselves (e.g. Table 1) and Kendall et al. (Kendall et al. 2015) that LDH binds to particles and therefore could interfere with this assay. For this reason, we used the MTT assay, which is a measure of mitochondrial activity, to investigate particle toxicity (Weyermann et al. 2005; Mosmann 1983). It has been observed across the literature that cationic particles, including polystyrene, are toxic to cells (Wang, Yu, et al. 2013), as observed similarly here with aPS particles (Figure 1A), where coating the particles decreased, but did not oblate their toxicity. Similar observations were made for CPS and UPS particles, where coating them with BALF decreased any differences in cellular activity between exposed and non-exposed particles. Given the increase was present at very low concentrations, we hypothesised that this increase could be due to a secreted factor in response to particulate exposure that may propagate an energy-dependent reaction, such as an inflammatory mechanism, within the cells. We therefore investigated a number of proinflammatory cytokines by quantitative-PCR, but found no increased levels of mRNA for interleukin (IL)-4, IL-6 or tumour necrosis factor receptor 1 (data not shown). When coated in BALF, there was no change in cellular response for either CPS or UPS, suggesting that these particles were biologically inert to A549 cells, which may be true in vivo, or the concentration of the particles used in the assay was below what is required for an acute inflammatory response from this cell line. $\mathrm{TiO}_{2}$ particles did not have any effect on mitochondrial activity when they were uncoated, however, there was an increase in insoluble formazan of approximately $50 \%$ at low concentrations for BALF-coated, showing different behaviour from cPS and uPS particles.

In vivo, particles become rapidly coated in proteins and lipids, and this process has been extensively studied in serum and media (Kendall et al. 2015). The primary route of exposure to airborne particles is due to inhalation and therefore studies in serum may not be relevant to environmental (pollutant) or inhaled nanotherapeutics (Wittgen et al. 2007). Therefore, we investigated the protein corona of NPs in BALF, which contains aqueous material from the lining fluid of pulmonary alveoli. Frequently, descriptions of protein coronas do not contain quantitative information of individual proteins and therefore analysis of the protein characteristics of the NP corona does not account for individual proteins present in high abundance. We have described the NP corona using high resolution MS to obtain quantitative information that we have used to weight the particle descriptions, thereby describing a more accurate representation of the particle corona.

The number of proteins bound to the particles was variable over time, particularly for aPS particles, (supplementary figure S2) upon which the number of proteins varied between 300 and 1000 per particle, suggesting highly dynamic binding kinetics. As discussed later, a relatively small number of proteins account for a large percentage of the corona and therefore this variability may be dictated 
by low abundance proteins. The $\mathrm{TiO}_{2}$ particles bound a similar number of proteins per particle compared with large polystyrene NPs despite being approximately $7 x$ smaller and therefore having in the order of $49 x$ less surface area per particle. The size of $\mathrm{TiO}_{2} \mathrm{NPs}$, as determined by TEM, was approximately $14 \mathrm{~nm}$ in PBS, however, by hydrodynamic diameter this was measured at $186 \mathrm{~nm}$, suggesting agglomeration in solution. Therefore, it is possible that the number of particles present in the TEM samples was an underestimation, the variation in size making the calculation error prone for $\mathrm{TiO}_{2}$ (the polystyrene particles were more homogenous and therefore the number of particles is more reliable for these particles).

There were few differences in the corona between any of the particles at any time points (Figure 4) and therefore it is unlikely that the protein corona formed within the lung would predict cellular uptake as reported elsewhere (Walkey et al. 2014). The proteins tended to be acidic and hydrophilic, although BALF may be enriched for such proteins as it is obtained using aqueous saline solution. There was conservation between the most abundant corona proteins, not only through time, but also between different particles (Table 1-3), suggesting that there is a small subset of proteins that dominate the protein corona. We investigated the composition of BALF to see if they bound through a concentration dependant manner, or if there could be a bio-physical attraction driving their adherence. The most abundant proteins on the corona were not necessarily the most abundant in BALF (Figure 3) although they tended to be amongst the top $50 \%$ of BALF-proteins. Not all of the proteins identified on the particles were identified in BALF alone, which suggests an enrichment of low abundance proteins on the particle surface (Bantscheff et al. 2007). The Vroman theory of protein exchange at hydrophobic surfaces, where high abundance, low affinity proteins are be exchanged over time for more strongly adherent but lower abundance proteins (Vroman 1962; Vroman \& Adams 1969), has been applied to NP-protein interactions (Casals et al. 2010; Jung et al. 2003). In part, our data supports this, since we see some proteins that are in high abundance in BALF also on the particles, but, analysis over time showed that these proteins were not exchanged. It has been demonstrated in serum that a stable corona can be formed in under 2 minutes (Dobrovolskaia et al. 2014; Tenzer et al. 2013). Our data shows that after 15 minutes, there is very little change in most of the protein bound to the particles, but there is change in the lower abundance proteins. Furthermore, clustering analysis demonstrated that there was not simply an on-off exchange of proteins but a number of distinct modalities and that protein binding could not be predicted based on their physiochemical properties. This finding may not be surprising when considering the scale between the nanoparticle and a protein. SP-A, one of the most abundant protein identified is approximately $40 \mathrm{~nm}$ in length and therefore is similar size to the $\mathrm{PS}$ and $\mathrm{TiO}_{2}$ particles used here. Therefore it is unlikely that the affinity of single functional groups will contribute greatly to the binding of the protein, rather the avidity of the particle surface.

Since the NPs coronae are similar the effects on MTT reduction may be independent of the NP corona (Ehrenberg et al. 2009), in keeping with lysosomal-bursting hypothesis of cationic particle toxicity (Bexiga et al. 2011; Wang, Bexiga, et al. 2013).

Bronchoalveolar lavage fluid is a mixture of lipids and proteins, therefore lipids maybe binding at the particle surface. The concentration of phospholipids, the predominant lipid species (Pérez-Gil 2008) was determined to be $<10 \mu \mathrm{g} / \mathrm{mL}$, therefore protein was in large excess in comparison. That said, proteins known to interact with pulmonary lipids, such as SP-A, SP-B (Table 3) and SP-D (SF1) were found on the particles' surface. SP-A and SP-D have been shown to bind to NP particles and affect their phagocytosis (McKenzie et al. 2015; Kendall et al. 2012).

Here we show that the particles may bind these proteins in vivo. In particular, SP-A was present in high abundance on all particles. SP-A has multiple functions in innate immunity, PSf spreading and 
recycling (Kishore et al. 2006). SP-B, which was also observed to bind to NPs is a hydrophobic protein that interacts and assists spreading of PSf to maintain low surface tension (Schürch et al. 2010). Hence, sequestering of these surfactant proteins could have an influence of the surface tension lowering properties of surfactant. Furthermore, as discussed in the introduction, airborne NPs have been shown to have a detrimental effect on mortality, particularly amongst people with respiratory diseases (Kendall \& Holgate 2012; Mackay et al. 2016). Mice made deficient for SP-A or SP-D have impaired surfactant metabolism and substructures (Korfhagen et al. 1998; Botas et al. 1998) and an impaired innate immune defence against bacterial and viral infections (Korfhagen et al. 1996; Pastva et al. 2007).

At the air-liquid interface of the lung, PSf is a barrier to nanoparticle entry into the hydrophase. Nanoparticles can/must pass through this before reaching the hydrophase beneath (Choi et al. 2010; Hu et al. 2013). Particles have been shown to bind to lipids from this layer (Kendall 2007; Ruge et al. 2012; Gonzalez et al. 1991) therefore inclusion of this layer is essential for a full description of nanoparticle-interactions with pulmonary fluids (Schleh et al. 2013). The BALF used throughout these experiments contained trace lipids species that could be identified by mass spectrometry (data not shown) and we observed the binding of proteins known to interact with PSf lipids. Nanoparticles have been shown to affect the functioning of PSf monolayers in vitro (Beck-Broichsitter et al. 2011; Dwivedi et al. 2014) and in silico (Hu et al. 2013; Lin et al. 2014), therefore future work would benefit from including a full description of the lipid corona.

The BALF used was taken from patients with pulmonary alveolar proteinosis (PAP), a disease characterised by a reduction in clearance of PSf and consequently is rich in lipids and surfactant associated proteins (Seymour \& Presneill 2002; Shah 2000). The presence of SP-A as a dominant protein on the particles' surface may be as a consequence of its exaggerated abundance in PAPBALF, in which it is known to be high. However, in the analysis of BALF only, it was only the $50^{\text {th }}$ most concentrated protein detected (Figure 3, Q8IWL1). Therefore there may also be significant binding of SP-A in non-PAP BALF, particularly as it is profuse in PSf.

\section{Conclusion}

A nanoparticle-surface corona forms quickly and stably following their incubation in BALF. Few proteins are bound in very high abundance on the surface, but those that are, are conserved over time and between particle types. The binding of proteins is independent of particle functionalisation, such upon inhalation, nanoparticle surfaces will become averaged, regardless of their intrinsic properties. We have detected the presence of PSf lipids binding to the surface of the particles (data not shown) that may further abrogate the intrinsic characteristics of the particle; this is currently under further investigation. We observe that there is a potential for pathological effects due to binding of surfactant-associated proteins and lipids to the particle surface.

\section{Acknowledgments}

We gratefully acknowledge the financial support of the University of Southampton for H.J.W (Vice Chancellor's Scholarship, Faculty of Medicine Doctoral Training Account and INTERFACE FUND Faculty of Medicine Research Management Committee and Faculty of Physical and Applied Sciences). The use of FENAC (Facility for Environmental Nanoscience Analysis and Characterisation) was supported by Natural Environment Research Council FENAC access grant 2013/05/004. This work was also supported by the National Institute of Health Research (NIHR) funded Respiratory Biomedical Research Units of University Hospital Southampton and the Royal Brompton and Harefield NHS Foundation Trust. 


\section{Declaration of Interest}

The authors do not have any competing financial interests with the work in this article.

\section{References}

Bakshi, M.S. et al., 2008. Metal nanoparticle pollutants interfere with pulmonary surfactant function in vitro. Biophysical journal, 94(3), pp.855-68.

Bantscheff, M. et al., 2007. Quantitative mass spectrometry in proteomics: a critical review. Analytical and bioanalytical chemistry, 389(4), pp.1017-31.

Beck-Broichsitter, M. et al., 2011. Biophysical investigation of pulmonary surfactant surface properties upon contact with polymeric nanoparticles in vitro. Nanomedicine : nanotechnology, biology, and medicine, 7(3), pp.341-50.

Bexiga, M.G. et al., 2011. Cationic nanoparticles induce caspase 3-, 7- and 9mediated cytotoxicity in a human astrocytoma cell line. Nanotoxicology, 5(4), pp.557-67.

Botas, C. et al., 1998. Altered surfactant homeostasis and alveolar type II cell morphology in mice lacking surfactant protein D. Proceedings of the National Academy of Sciences of the United States of America, 95(20), pp.11869-74.

Casals, E. et al., 2010. Time evolution of the nanoparticle protein corona. ACS nano, 4(7), pp.3623-32.

Cedervall, T. et al., 2007. Detailed identification of plasma proteins adsorbed on copolymer nanoparticles. Angewandte Chemie (International ed. in English), 46(30), pp.5754-6.

Choe, S. et al., 2008. Molecular dynamics simulation study of a pulmonary surfactant film interacting with a carbonaceous nanoparticle. Biophysical journal, 95(9), pp.4102-14.

Choi, H.S. et al., 2010. Rapid translocation of nanoparticles from the lung airspaces to the body. Nature biotechnology, 28(12), pp.1300-3.

Commission, E., 2011. Commission Recommendation of 18 October 2011 on the definition of nanomaterial. Official Journal of the European Union, 54, pp.38-40.

Dobrovolskaia, M.A. et al., 2014. Protein corona composition does not accurately predict hematocompatibility of colloidal gold nanoparticles. Nanomedicine : nanotechnology, biology, and medicine, 10(7), pp.1453-63.

Dwivedi, M. V et al., 2014. Size influences the effect of hydrophobic nanoparticles on lung surfactant model systems. Biophysical journal, 106(1), pp.289-98.

Ehrenberg, M.S. et al., 2009. The influence of protein adsorption on nanoparticle association with cultured endothelial cells. Biomaterials, 30(4), pp.603-10.

Fan, Q. et al., 2011. Adverse biophysical effects of hydroxyapatite nanoparticles on natural pulmonary surfactant. ACS nano, 5(8), pp.6410-6.

Gonzalez, F.G., Vilchez, M.A.C. \& Hidalgo-Alvarez, R., 1991. Adsorption of anionic surfactants on positively charged polystyrene particles II. Colloid \& Polymer Science, 269(4), pp.406-411. 
Honda, Y. et al., 1995. Pulmonary surfactant protein D in sera and bronchoalveolar lavage fluids. American journal of respiratory and critical care medicine, 152(6 Pt 1), pp.1860-6.

Honda, Y., 1993. Surfactant protein-A concentration in bronchoalveolar lavage fluids of patients with pulmonary alveolar proteinosis. CHEST Journal, 103(2), p.496.

Hu, G. et al., 2013. Physicochemical properties of nanoparticles regulate translocation across pulmonary surfactant monolayer and formation of lipoprotein corona. ACS nano, 7(12), pp.10525-33.

Jung, S.-Y. et al., 2003. The Vroman effect: a molecular level description of fibrinogen displacement. Journal of the American Chemical Society, 125(42), pp.12782-6.

Kendall, M., 2007. Fine airborne urban particles (PM2.5) sequester lung surfactant and amino acids from human lung lavage. American journal of physiology. Lung cellular and molecular physiology, 293(4), pp.L1053-8.

Kendall, M. et al., 2015. Nanoparticle growth and surface chemistry changes in cellconditioned culture medium. Philosophical transactions of the Royal Society of London. Series B, Biological sciences, 370(1661).

Kendall, M. et al., 2012. Surfactant protein D (SP-D) alters cellular uptake of particles and nanoparticles. Nanotoxicology.

Kendall, M. \& Holgate, S., 2012. Health impact and toxicological effects of nanomaterials in the lung. Respirology (Carlton, Vic.), 17(5), pp.743-58.

Kishore, U. et al., 2006. Surfactant proteins SP-A and SP-D: Structure, function and receptors. Molecular Immunology, 43(9), pp.1293-1315.

Korfhagen, T.R. et al., 1996. Altered surfactant function and structure in SP-A gene targeted mice. Proceedings of the National Academy of Sciences of the United States of America, 93(18), pp.9594-9.

Korfhagen, T.R. et al., 1998. Surfactant protein-D regulates surfactant phospholipid homeostasis in vivo. The Journal of biological chemistry, 273(43), pp.28438-43.

Laden, F. et al., 2000. Association of fine particulate matter from different sources with daily mortality in six U.S. cities. Environmental health perspectives, 108(10), pp.941-7.

Laden, F. et al., 2006. Reduction in fine particulate air pollution and mortality: Extended follow-up of the Harvard Six Cities study. American journal of respiratory and critical care medicine, 173(6), pp.667-72.

Lin, X. et al., 2014. Promote potential applications of nanoparticles as respiratory drug carrier: insights from molecular dynamics simulations. Nanoscale, 6(5), pp.2759-67.

Mackay, R.-M.A. et al., 2016. Airway surfactant protein D (SP-D) deficiency in adults with severe asthma. Chest.

McKenzie, Z., Kendall, M., Mackay, R.-M., Tetley, T.D., et al., 2015. Nanoparticles modulate surfactant protein $A$ and $D$ mediated protection against influenza $A$ infection in vitro. Philosophical transactions of the Royal Society of London. Series B, Biological sciences, 370(1661), p.20140049. 
McKenzie, Z., Kendall, M., Mackay, R.-M., Whitwell, H., et al., 2015. Surfactant protein $\mathrm{A}(\mathrm{SP}-\mathrm{A})$ inhibits agglomeration and macrophage uptake of toxic amine modified nanoparticles. Nanotoxicology, 5390(2008), pp.1-11.

Mosmann, T., 1983. Rapid colorimetric assay for cellular growth and survival: application to proliferation and cytotoxicity assays. Journal of immunological methods, 65(1-2), pp.55-63.

Oberdörster, G., Oberdörster, E. \& Oberdörster, J., 2005. Nanotoxicology: An Emerging Discipline Evolving from Studies of Ultrafine Particles. Environmental Health Perspectives, 113(7), pp.823-839.

Pastva, A.M., Wright, J.R. \& Williams, K.L., 2007. Immunomodulatory roles of surfactant proteins A and D: implications in lung disease. Proceedings of the American Thoracic Society, 4(3), pp.252-7.

Pérez-Gil, J., 2008. Structure of pulmonary surfactant membranes and films: the role of proteins and lipid-protein interactions. Biochimica et biophysica acta, 1778(78), pp.1676-95.

Pope, C.A. et al., 2004. Cardiovascular mortality and long-term exposure to particulate air pollution: epidemiological evidence of general pathophysiological pathways of disease. Circulation, 109(1), pp.71-7.

Ruge, C. a et al., 2012. The interplay of lung surfactant proteins and lipids assimilates the macrophage clearance of nanoparticles. PloS one, 7(7), p.e40775.

Samet, J.M. et al., 2000. Fine particulate air pollution and mortality in 20 U.S. cities, 1987-1994. The New England journal of medicine, 343(24), pp.1742-9.

Schäffler, M. et al., 2013. Serum protein identification and quantification of the corona of 5, 15 and $80 \mathrm{~nm}$ gold nanoparticles. Nanotechnology, 24(26), p.265103.

Schleh, C. \& Hohlfeld, J.M., 2009. Interaction of nanoparticles with the pulmonary surfactant system. Inhalation toxicology, 21 Suppl 1, pp.97-103.

Schleh, C., Kreyling, W.G. \& Lehr, C.-M., 2013. Pulmonary surfactant is indispensable in order to simulate the in vivo situation. Particle and fibre toxicology, 10(1), p.6.

Schürch, D. et al., 2010. Combined and independent action of proteins SP-B and SP-C in the surface behavior and mechanical stability of pulmonary surfactant films. Biophysical journal, 99(10), pp.3290-9.

Schütz, C.A. et al., 2013. Therapeutic nanoparticles in clinics and under clinical evaluation. Nanomedicine (London, England), 8(3), pp.449-67.

Seymour, J.F. \& Presneill, J.J., 2002. Pulmonary alveolar proteinosis: progress in the first 44 years. American journal of respiratory and critical care medicine, 166(2), pp.215-35.

Shah, P.L., 2000. Rare diseases bullet 6: Pulmonary alveolar proteinosis: clinical aspects and current concepts on pathogenesis. Thorax, 55(1), pp.67-77.

Strong, P. et al., 1998. A novel method of purifying lung surfactant proteins $A$ and $D$ from the lung lavage of alveolar proteinosis patients and from pooled amniotic fluid. Journal of immunological methods, 220(1-2), pp.139-49. 
Tenzer, S. et al., 2013. Rapid formation of plasma protein corona critically affects nanoparticle pathophysiology. Nature Nanotechnology, 8(10), pp.772-781.

Vroman, L., 1962. Effect of Adsorbed Proteins on the Wettability of Hydrophilic and Hydrophobic Solids. Nature, 196(4853), pp.476-477.

Vroman, L. \& Adams, A.L., 1969. Findings with the recording ellipsometer suggesting rapid exchange of specific plasma proteins at liquid/solid interfaces. Surface Science, 16, pp.438-446.

Walkey, C.D. et al., 2014. Protein Corona Fingerprinting Predicts the Cell Association of Gold Nanoparticles. ACS nano.

Wang, F., Yu, L., et al., 2013. The biomolecular corona is retained during nanoparticle uptake and protects the cells from the damage induced by cationic nanoparticles until degraded in the lysosomes. Nanomedicine : nanotechnology, biology, and medicine, null(null).

Wang, F., Bexiga, M.G., et al., 2013. Time resolved study of cell death mechanisms induced by amine-modified polystyrene nanoparticles. Nanoscale, 5(22), pp.10868-10876.

Ward, C. et al., 1997. Albumin is not suitable as a marker of bronchoalveolar lavage dilution in interstitial lung disease. The European respiratory journal, 10(9), pp.2029-33.

Weyermann, J., Lochmann, D. \& Zimmer, A., 2005. A practical note on the use of cytotoxicity assays. International journal of pharmaceutics, 288(2), pp.369-76.

Wittgen, B.P.H. et al., 2007. Phase I study of aerosolized SLIT cisplatin in the treatment of patients with carcinoma of the lung. Clinical cancer research : an official journal of the American Association for Cancer Research, 13(8), pp.241421. 


\begin{tabular}{|l|l|l|l|l|}
\hline & aPS 60min & cPS 60min & uPS 60min & TiO $_{\mathbf{2}} \mathbf{6 0 m i n}$ \\
\hline $\mathbf{1}$ & Actin, cytoplasmic 1 & $\begin{array}{l}\text { Pulmonary surfactant- } \\
\text { associated protein A1 }\end{array}$ & Actin, cytoplasmic 1 & $\begin{array}{l}\text { Pulmonary surfactant- } \\
\text { associated protein A1 }\end{array}$ \\
\hline $\mathbf{2}$ & $\begin{array}{l}\text { L-lactate dehydrogenase } \\
\text { A-like 6A }\end{array}$ & Actin, cytoplasmic 1 & $\begin{array}{l}\text { Pulmonary surfactant- } \\
\text { associated protein A1 }\end{array}$ & Actin, cytoplasmic 1 \\
\hline $\mathbf{3}$ & $\begin{array}{l}\text { Pulmonary surfactant- } \\
\text { associated protein A1 }\end{array}$ & $\begin{array}{l}\text { L-lactate dehydrogenase } \\
\text { A-like 6A }\end{array}$ & Serum albumin & $\begin{array}{l}\text { L-lactate dehydrogenase } \\
\text { A-like 6A }\end{array}$ \\
\hline $\mathbf{4}$ & $\begin{array}{l}\text { Heat shock cognate 71 } \\
\text { kDa protein }\end{array}$ & Serum albumin & $\begin{array}{l}\text { Heat shock cognate 71 } \\
\text { kDa protein }\end{array}$ & Alpha-actinin-4 \\
\hline $\mathbf{5}$ & Ezrin & Moesin & Moesin & Moesin \\
\hline $\mathbf{6}$ & Moesin & Annexin A2 & $\begin{array}{l}\text { L-lactate dehydrogenase } \\
\text { A-like 6A }\end{array}$ & $\begin{array}{l}\text { POTE ankyrin domain } \\
\text { family member E }\end{array}$ \\
\hline $\mathbf{7}$ & Annexin A2 & Alpha-actinin-4 & Annexin A2 \\
\hline $\mathbf{8}$ & Serum albumin & Alpha-3-3 protein zeta/delta & $\begin{array}{l}\text { POTE ankyrin domain } \\
\text { family member E }\end{array}$ & Ras-related protein Rab-8A \\
\hline $\mathbf{9}$ & Alpha-actinin-2 & Alpha-actinin-4 & Annexin A2 & Serum albumin \\
\hline $\mathbf{1 0}$ & $\begin{array}{l}\text { Dihydropyrimidinase- } \\
\text { related protein 2 }\end{array}$ & Ig alpha-1 chain C region & $\begin{array}{l}\text { Dihydropyrimidinase- } \\
\text { related protein 2 }\end{array}$ & $\begin{array}{l}\text { Keratin, type II cytoskeletal } \\
8\end{array}$ \\
\hline
\end{tabular}

Table 1: Top 10 Proteins After 60 Minutes. Top 10 most abundant proteins bound to each particle after 60 minutes of incubation in BALF. Proteins with a grey back ground were identified on all particles. 


\begin{tabular}{|c|c|c|c|c|}
\hline$\#$ & aPS 15min & aPS 30min & aPS 60min & aPS 120min \\
\hline 1 & $\begin{array}{l}\text { Pulmonary surfactant- } \\
\text { associated protein A1 }\end{array}$ & Actin_cytoplasmic 1 & Actin_cytoplasmic 1 & $\begin{array}{l}\text { Pulmonary surfactant- } \\
\text { associated protein A1 }\end{array}$ \\
\hline 2 & Actin_cytoplasmic 1 & $\begin{array}{l}\text { Pulmonary surfactant- } \\
\text { associated protein A1 }\end{array}$ & $\begin{array}{l}\text { Pulmonary surfactant- } \\
\text { associated protein A1 }\end{array}$ & Actin_cytoplasmic 1 \\
\hline 3 & Protein tweety homolog & Protein tweety homolog & Protein tweety homolog & DNA repair protein RAD50 \\
\hline 4 & Moesin & Beta-actin-like protein 2 & Beta-actin-like protein 2 & Moesin \\
\hline 5 & Serum albumin & Moesin & Keratin_type II cyt & $\begin{array}{l}\text { POTE ankyrin domain } \\
\text { family member } E\end{array}$ \\
\hline 6 & $\begin{array}{l}\text { Guanine nucleotide- } \\
\text { binding protein } \mathrm{G}(\mathrm{s}) \\
\text { subunit alpha isoforms } \\
\text { XLas }\end{array}$ & Serum albumin & Moesin & Serum albumin \\
\hline 7 & Mucin-1 subunit alpha & $\begin{array}{l}\text { Coiled-coil domain- } \\
\text { containing protein } 167 \\
\text { (Fragment) }\end{array}$ & Keratin_type I cyt & $\begin{array}{l}\text { Terminal } \\
\text { uridylyltransferase } 4\end{array}$ \\
\hline 8 & Annexin A2 & Annexin A2 & Annexin A2 & $\begin{array}{l}\text { Guanine nucleotide- } \\
\text { binding protein } \mathrm{G}(\mathrm{s}) \\
\text { subunit alpha isoforms } \\
\text { XLas }\end{array}$ \\
\hline 9 & $\begin{array}{l}\text { HLA class II } \\
\text { histocompatibility } \\
\text { antigen_DRB1-1 beta } \\
\text { chain }\end{array}$ & Myosin-14 & Serum albumin & $\begin{array}{l}\text { Pulmonary surfactant- } \\
\text { associated protein B }\end{array}$ \\
\hline 10 & $\begin{array}{l}\text { Chloride intracellular } \\
\text { channel protein } 1\end{array}$ & $\begin{array}{l}\text { Beta/gamma crystallin } \\
\text { domain-containing } \\
\text { protein } 3\end{array}$ & $\begin{array}{l}\text { Keratin_type I } \\
\text { cytoskeletal } 9\end{array}$ & $\begin{array}{l}\text { Sodium-dependent } \\
\text { phosphate transport } \\
\text { protein 2B }\end{array}$ \\
\hline
\end{tabular}

Table 2: Top 10 Proteins on aPS Particles.Top 10 most abundant proteins at each time point for aPS particles. Proteins with grey back ground were identified at all time points. 


\begin{tabular}{|l|l|l|l|l|}
\hline & cPS 15min & cPS 30min & cPS 60min & cPS 120min \\
\hline $\mathbf{1}$ & $\begin{array}{l}\text { Pulmonary surfactant- } \\
\text { associated protein A1 }\end{array}$ & $\begin{array}{l}\text { Pulmonary surfactant- } \\
\text { associated protein A1 }\end{array}$ & $\begin{array}{l}\text { Pulmonary surfactant- } \\
\text { associated protein A1 }\end{array}$ & $\begin{array}{l}\text { Pulmonary surfactant- } \\
\text { associated protein A1 }\end{array}$ \\
\hline $\mathbf{2}$ & Actin_cytoplasmic 1 & Actin_cytoplasmic 1 & Actin_cytoplasmic 1 & Actin_ cytoplasmic 1 \\
\hline $\mathbf{3}$ & $\begin{array}{l}\text { POTE ankyrin domain } \\
\text { family member E }\end{array}$ & $\begin{array}{l}\text { Pulmonary surfactant- } \\
\text { associated protein B }\end{array}$ & $\begin{array}{l}\text { Putative beta-actin-like } \\
\text { protein 3 }\end{array}$ & $\begin{array}{l}\text { Pulmonary surfactant- } \\
\text { associated protein B }\end{array}$ \\
\hline $\mathbf{4}$ & $\begin{array}{l}\text { Putative beta-actin-like } \\
\text { protein 3 }\end{array}$ & Serum albumin & Serum albumin & Serum albumin \\
\hline $\mathbf{5}$ & Serum albumin & Beta-actin-like protein 2 & Moesin & Annexin A2 \\
\hline $\mathbf{6}$ & $\begin{array}{l}\text { Pulmonary surfactant- } \\
\text { associated protein B }\end{array}$ & Moesin & Annexin A2 & Moesin \\
\hline $\mathbf{7}$ & Annexin A2 & $\begin{array}{l}\text { POTE ankyrin domain } \\
\text { family member E }\end{array}$ & Alpha-enolase & Ig kappa chain C region \\
\hline $\mathbf{8}$ & Moesin & Annexin A2 & Beta-2-glycoprotein 1 & Ig gamma-1 chain C region \\
\hline $\mathbf{9}$ & Elongation factor 2 & $\begin{array}{l}\text { Ig gamma-1 chain C } \\
\text { region }\end{array}$ & $\begin{array}{l}\text { Ig gamma-1 chain C } \\
\text { region }\end{array}$ & Alpha-enolase \\
\hline $\mathbf{1 0}$ & Keratin_type II cyt & Ig kappa chain C region & Ig alpha-1 chain C region & $\begin{array}{l}\text { Ig lambda-1 chain C } \\
\text { regions }\end{array}$ \\
\hline
\end{tabular}

Table 3: Top 10 Proteins on cPS Particles. Top 10 most abundant proteins at each time point for cPS particles. Proteins with a grey back ground were identified at all time points. 
Figures:

A

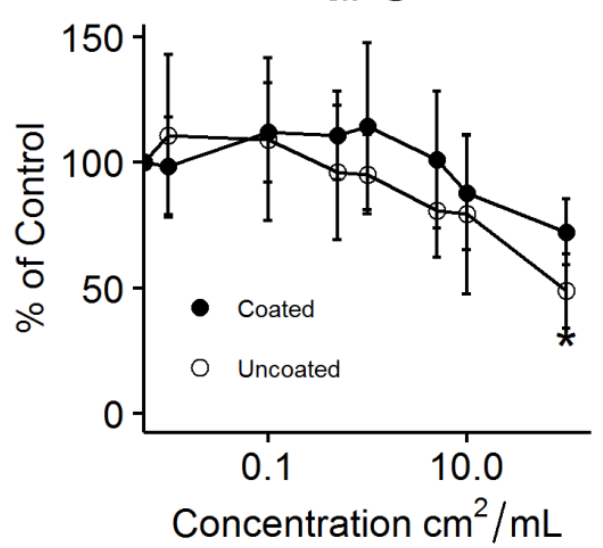

C

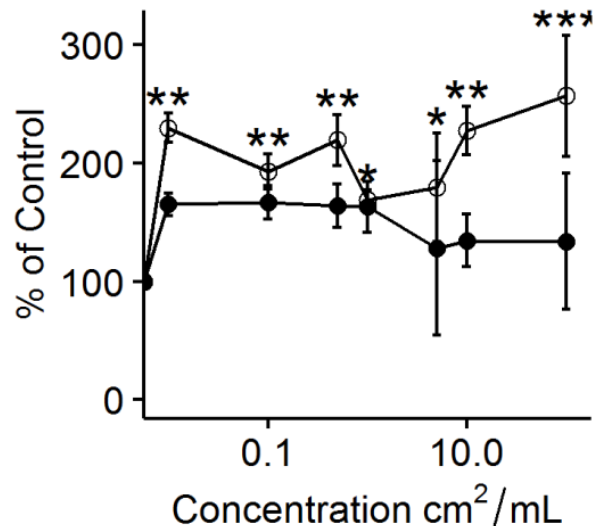

B

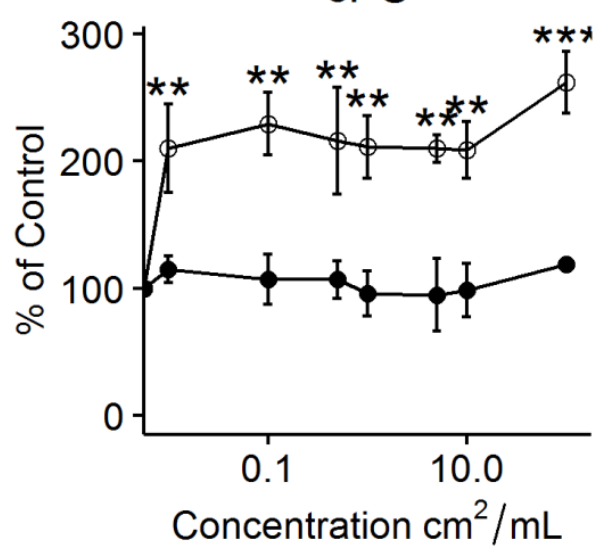

D

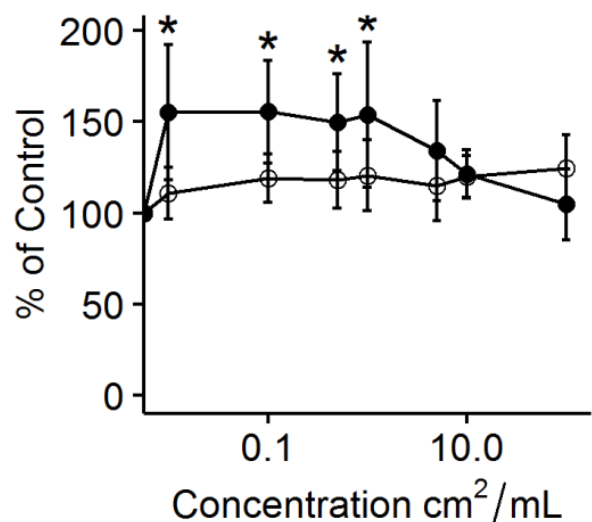

Figure 1: The effect of nanoparticles on mitochondrial activity. Particles were either prior incubated in BALF (black circles) or applied directly (white circles) to A549 cells in serum free media for 24 hours and assessed by the MTT assay. (A) aPS particles, (B) cPS particles, (C) uPS particles and (D) $\mathrm{TiO}_{2}$ particles. $\mathrm{N}=3$ independent experiments, each performed in triplicate. Mean \pm standard deviation. ${ }^{*} \mathrm{P}<0.05,{ }^{* *} \mathrm{P}<0.01,{ }^{* * *} \mathrm{P}<0.001$ (T-test, difference from untreated). 
A

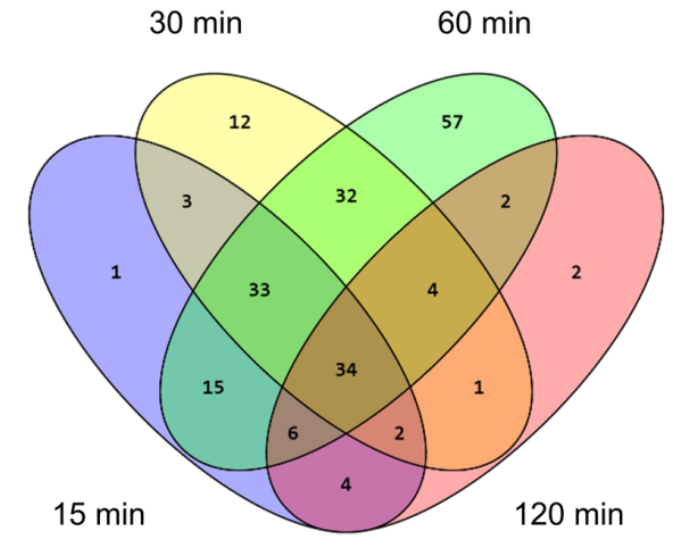

C

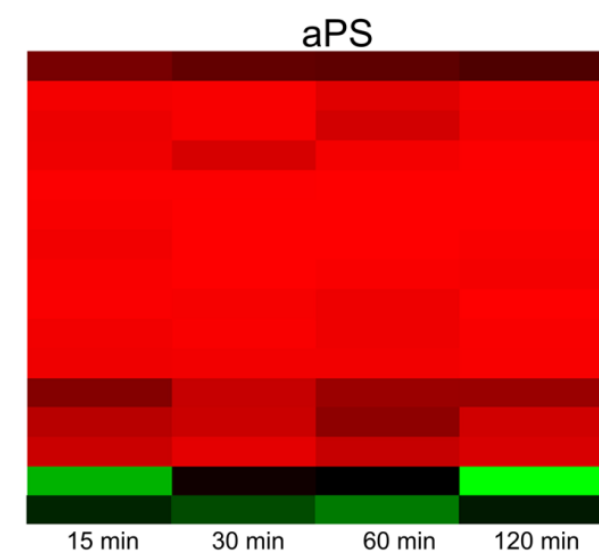

B

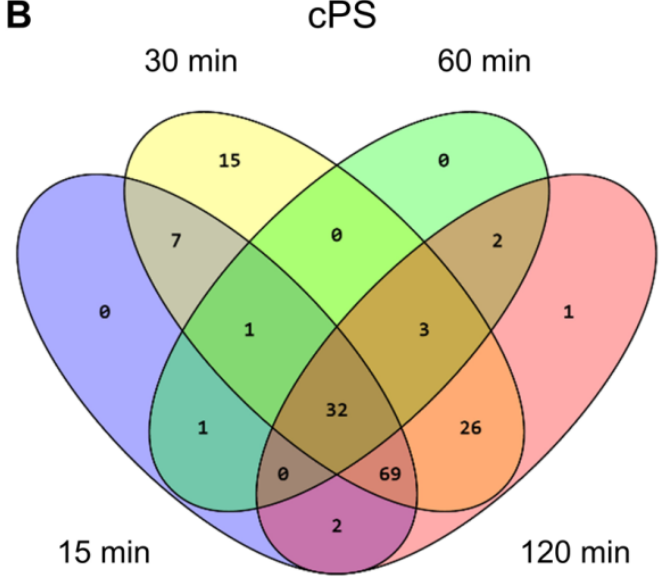

D

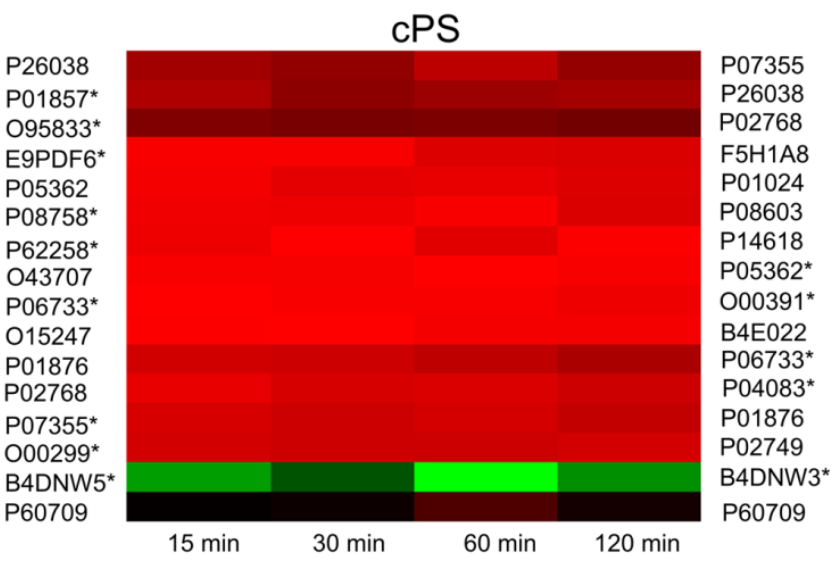

Figure 2: Proteins bound over time between aPS and cPS particles. (A) The number of identified proteins bound to aPS particles over four time points. (B) The number of identified proteins bound to cPS particles over four time points. (C and D) Heat maps showing the concentration of quantified proteins that were common to each time point for aPS and CPS respectively. Each protein was normalised by Z-score and clustered by non-hierarchical clustering. Uniprot accession numbers for each protein are given at the side and protein names are listed in supplementary file SF1 \& SF2. *P<0.05 difference between any two time points. 

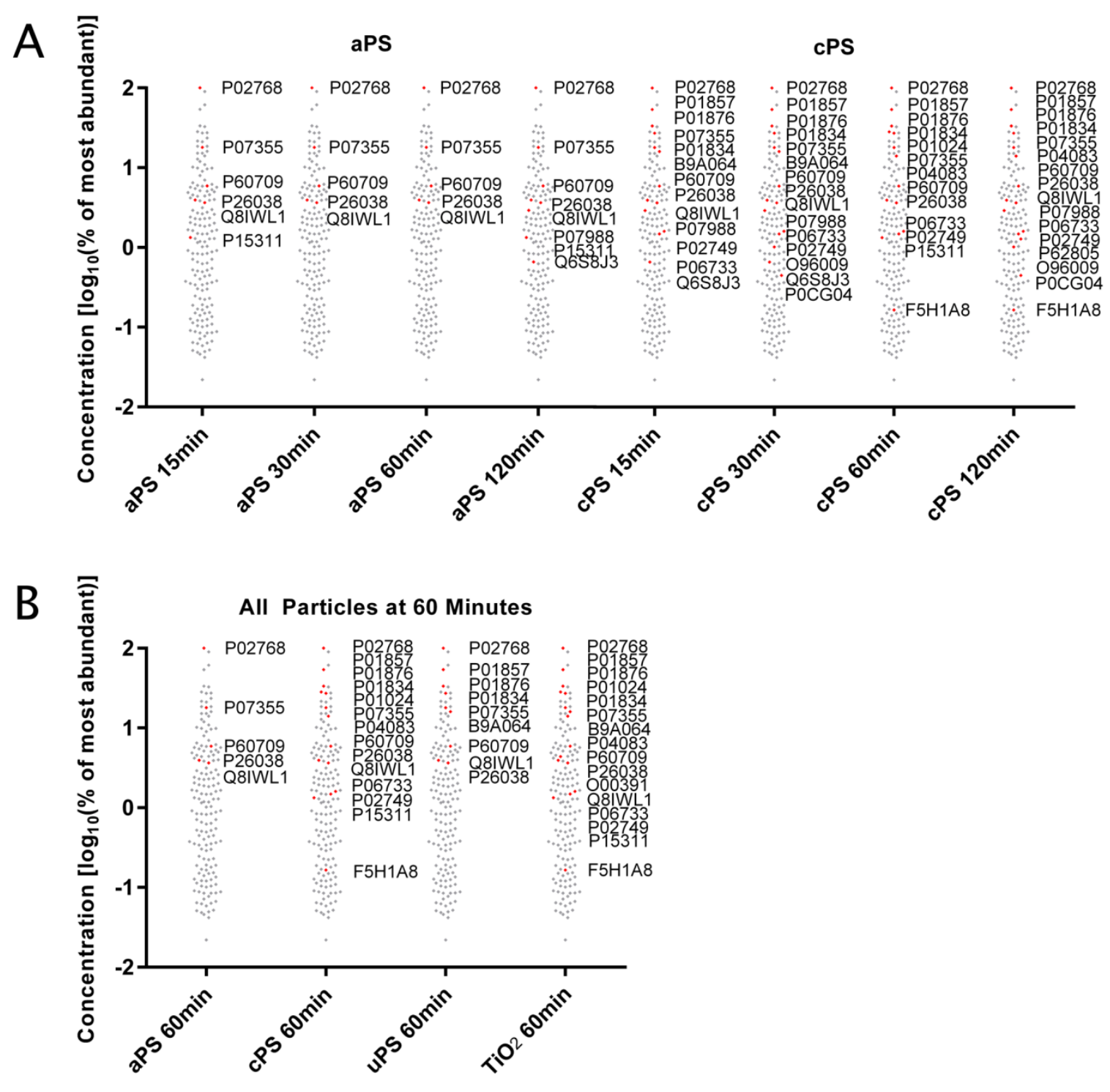

Figure 3: The distribution of proteins in BALF, ordered by abundance. Red points represent proteins that are amongst the top 20 protein eluted from the particle after incubation in BALF for (A) CPS and aPS over time and (B) all particles after 1 hour incubation in BALF. Since not all proteins that were detected on the particles were identified in BALF, not all top 20 proteins are depicted. Uniprot accession numbers for each red point are given and protein names are listed in supplementary file SF4. 
A Isoelectric Point

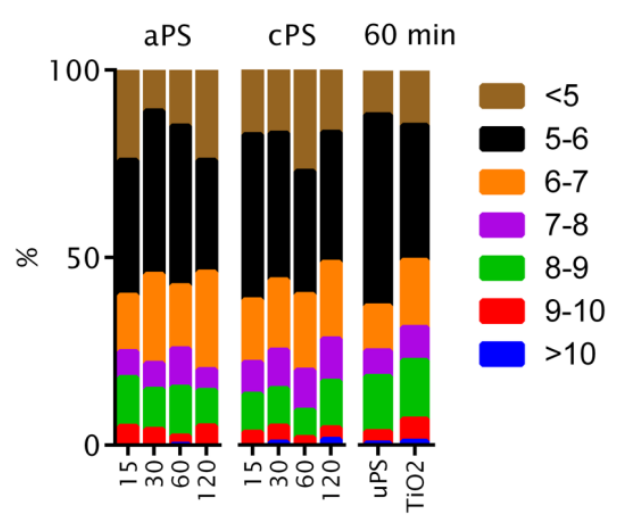

$$
\text { C }
$$

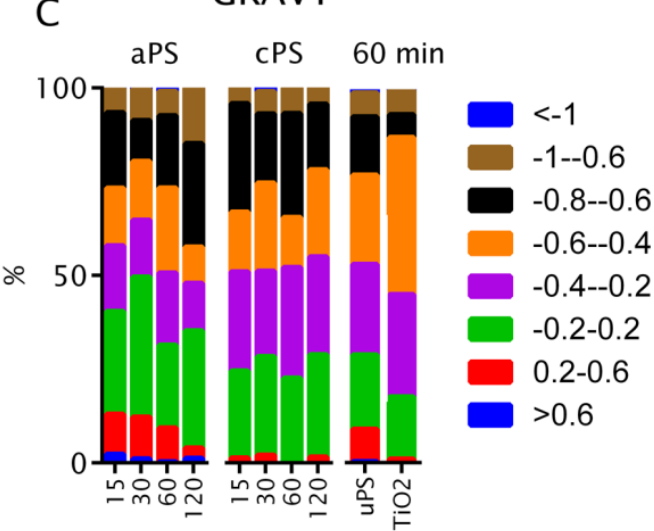

$$
\text { E }
$$

$\beta$-Sheet

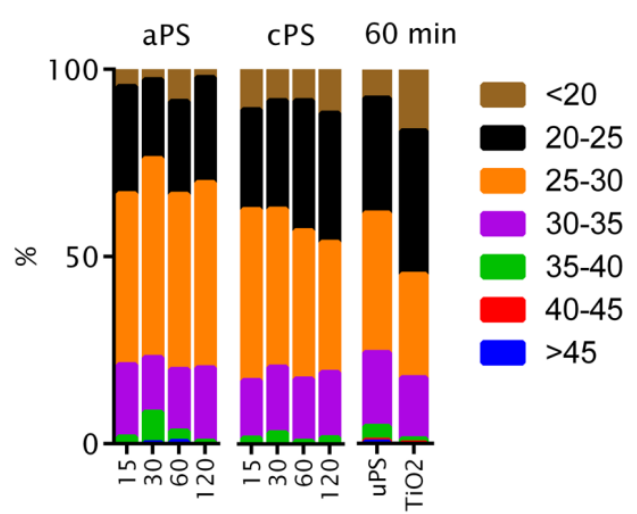

B Molecular Weight

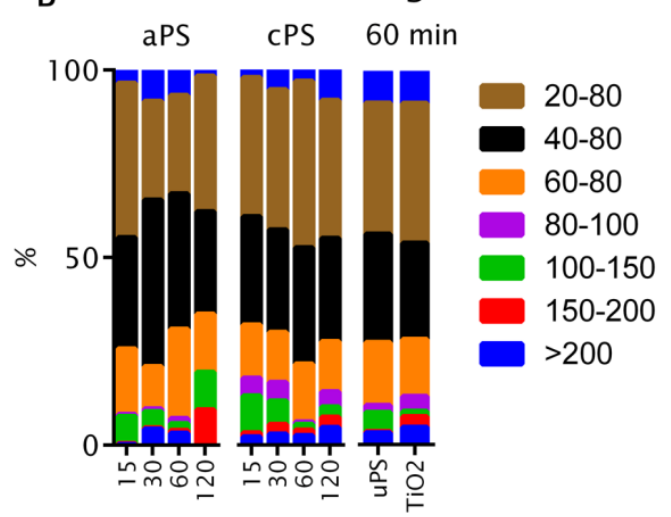

D aPS $\quad$ CPS 60 min

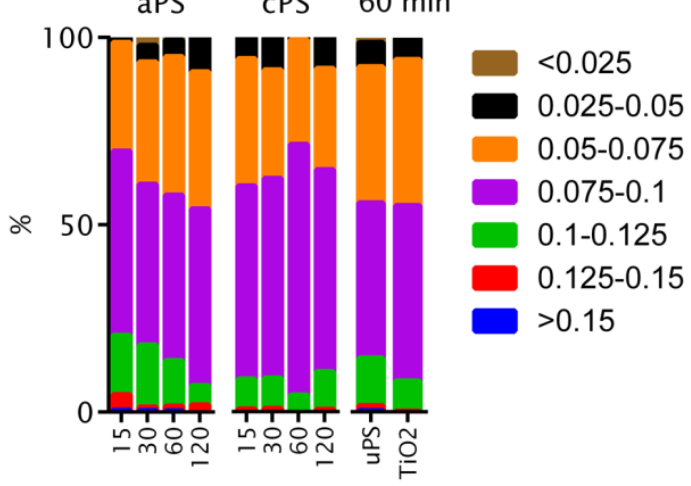

F Aromaticity

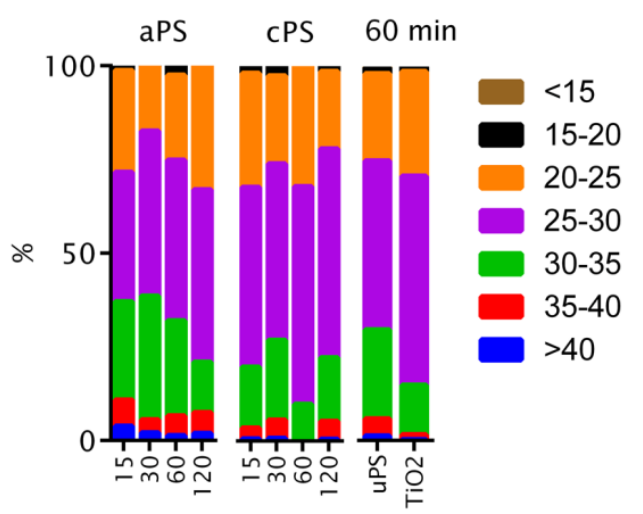

Figure 4: Distribution of physiochemical characteristics of corona proteins. (A) isoelectric point, (B) molecular weight, (C) Grand Average of Hydropathy (GRAVY), (D) aromatic index, (E) \% of predicted $\alpha$-helix or (F) \% of predicted $\beta$-sheet. Values were weighted by protein abundance. aPS and cPS particles were incubated in BALF for the time shown. UPS and $\mathrm{TiO}_{2}$ particles were incubated in BALF for 60 minutes. 

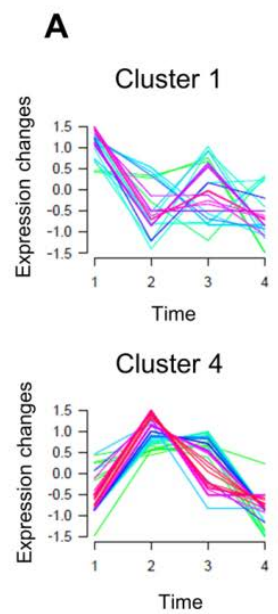

C
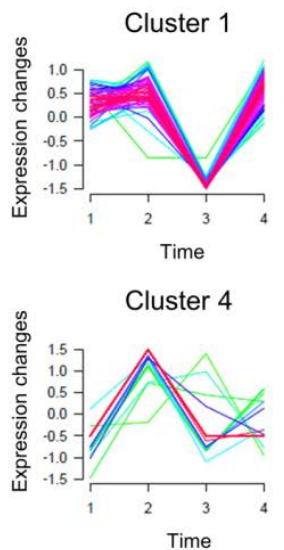

aPS

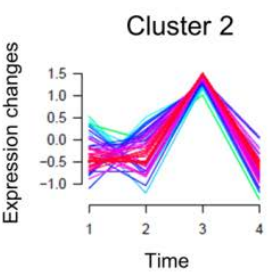

Membership

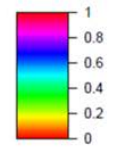

cPS

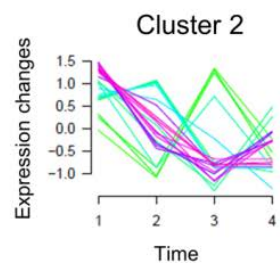

Membership

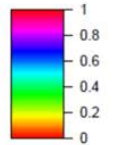

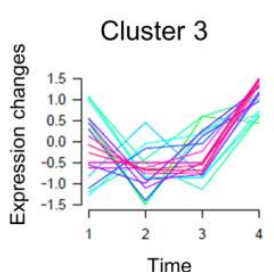

Distribution $\mathrm{n}=207$

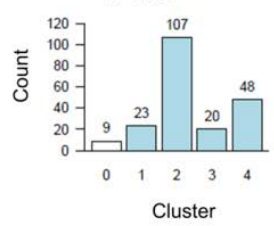

luster

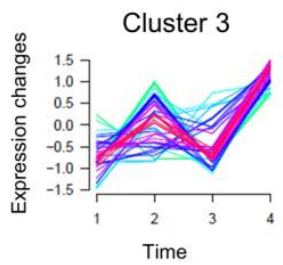

Distribution $\mathrm{n}=159$

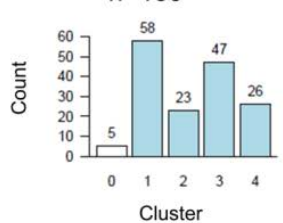

B

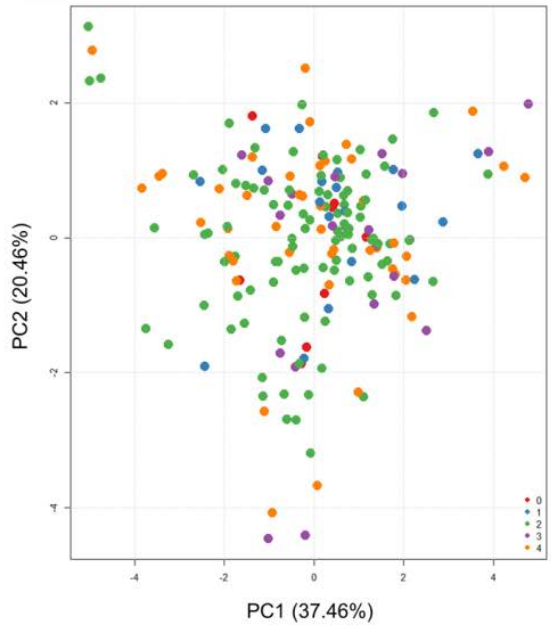

D

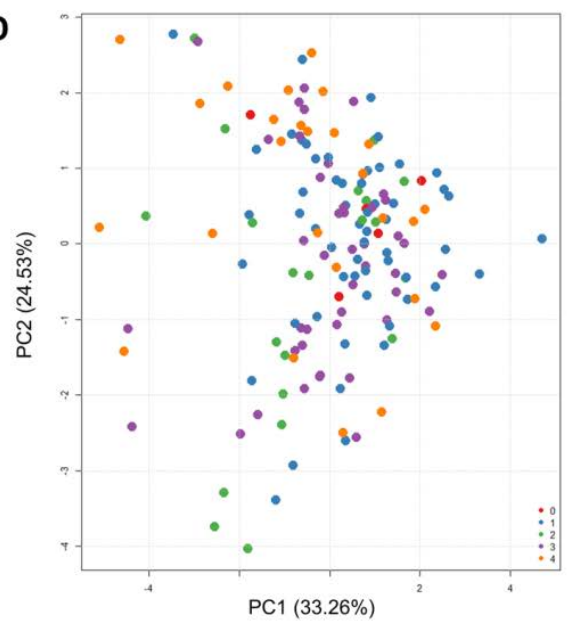

Figure 5: Non-hierarchical fuzzy clustering of proteins bound to aPS (A) and cPS (B) over time and PCA of the bound proteins physiochemical properties, coloured by cluster (C-D). Each particle was clustered into four groups, the degree of membership to each group is shown colourmetrically. For PCA analysis, blue (cluster 1), green (cluster 2 ), purple (cluster 3 ), orange (cluster 4 ). 


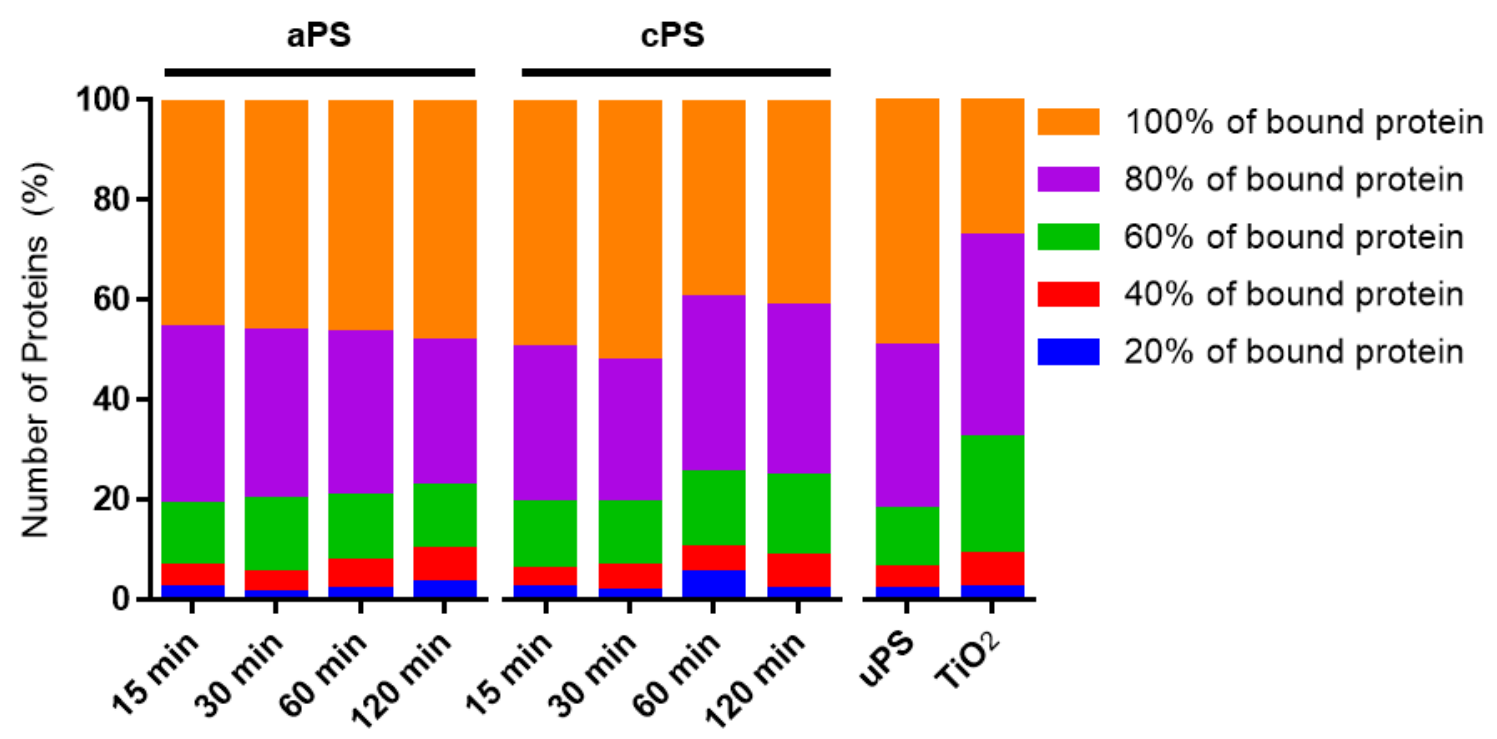

Figure 6: The distribution of the abundance of proteins for each particle corona. aPS and cPS particles were incubated for the time shown on the $\mathrm{x}$-axis whereas UPS and $\mathrm{TiO}_{2}$ were incubated in BALF for 60 minutes only. 


\section{Supplementary material}

\begin{tabular}{|c|l|l|l|}
\hline Particle & Media & $\begin{array}{l}\text { Z-Average } \\
\text { (nm) }\end{array}$ & $\begin{array}{l}\text { Poly Dispersity } \\
\text { Index }\end{array}$ \\
\hline \multirow{2}{*}{ aPS } & $\mathrm{H}_{2} \mathrm{O}$ & $174.5 \pm 0.04$ & $0.17 \pm 0.04$ \\
\cline { 2 - 4 } & $\mathrm{PBS}$ & $181.17 \pm 7.19$ & $0.19 \pm 0.03$ \\
\hline \multirow{2}{*}{ cPS } & $\mathrm{H}_{2} \mathrm{O}$ & $82.77 \pm 0.43$ & $0.05 \pm 0.01$ \\
\cline { 2 - 4 } & $\mathrm{PBS}$ & $83.76 \pm 4.55$ & $0.05 \pm 0.04$ \\
\hline \multirow{2}{*}{ uPS } & $\mathrm{H}_{2} \mathrm{O}$ & $111.5 \pm 11.42$ & $0.15 \pm 0.03$ \\
\cline { 2 - 4 } & $\mathrm{PBS}$ & $151.7 \pm 6.89$ & $0.18 \pm 0.03$ \\
\hline \multirow{2}{*}{$\mathrm{TiO}_{2}$} & $\mathrm{H}_{2} \mathrm{O}$ & 131 & 0.211 \\
\cline { 2 - 4 } & $\mathrm{PBS}$ & 255.9 & 0.158 \\
\hline \multirow{2}{*}{$\begin{array}{l}\text { Media } \\
\text { Only }\end{array}$} & $\mathrm{H}_{2} \mathrm{O}$ & 0.02 & 0.03 \\
\cline { 2 - 4 } & $\mathrm{PBS}$ & 631.5 & 0.67 \\
\hline
\end{tabular}

Supplementary Table ST1: Z-average and poly-dispersity index values from dynamic light scattering of $100 \mathrm{~nm}$ aPS, CPS, uPS and $14 \mathrm{~nm} \mathrm{TiO}_{2}$ in $\mathrm{H}_{2} \mathrm{O}$ and phosphate buffered saline (PBS). Readings for media-only are also given.

\begin{tabular}{|c|c|c|c|c|c|c|}
\hline Particle & Media & Size TEM (nm) & Size (AFM) (nm) & $\begin{array}{l}\text { Hydrodynamic } \\
\text { Diameter (nm) }\end{array}$ & $\begin{array}{l}\text { Zeta Potential } \\
(\mathrm{mV})\end{array}$ & Image \\
\hline \multirow[t]{2}{*}{ aPS } & PBS & \begin{tabular}{|l}
$154.86 \pm 96$ \\
(median=101.35)
\end{tabular} & $78.65 \pm 8.82$ & $115.9 \pm 7.89$ & $-11.5 \pm 1.81$ & \\
\hline & BALF & $293.14 \pm 383.59$ & $88.08 \pm 11.33$ & - & - & \\
\hline \multirow{2}{*}{ cPS } & PBS & $69.5 \pm 4.6$ & $55.31 \pm 8.06$ & $89.26 \pm 4.43$ & $-19.73 \pm 1.25$ & \\
\hline & BALF & $75.7 \pm 6.9$ & $56.1 \pm 5.4$ & - & - & \\
\hline \multirow{2}{*}{ uPS } & PBS & $77.7 \pm 11.7$ & $65.27 \pm 6.95$ & $90.53 \pm 8.06$ & $-17.07 \pm 0.90$ & \\
\hline & BALF & $78 \pm 24.7$ & $81.14 \pm 6.88$ & - & - & \\
\hline \multirow[b]{2}{*}{$\mathrm{TiO}_{2}$} & PBS & $14.09 \pm 7.26$ & - & $183(n=1)$ & $-22.7(n=1)$ & \\
\hline & BALF & $\begin{array}{l}76 \pm 134.9 \\
\text { (median=37) }\end{array}$ & - & - & - & \\
\hline
\end{tabular}

Supplementary Table ST2: Size of the particles was determined in either PBS or BALF by three different methods. Size determined from TEM and AFM is averaged from 100 particles.

Hydrodynamic diameter was taken in triplicate (unless otherwise stated) in PBS only and the 'Number' value is reported. All values are mean \pm standard deviation. - sample measurement not performed. TEM images of particles incubated in PBS are presented for an idea of particle shape and are not to scale.

Supplementary File SF1: Excel sheet: Summary of proteins detected bound to aPS particles at different time points. Raw data and normalised data.

Supplementary File SF2. Excel sheet: Summary of proteins detected bound to cPS particles at different time points. Raw data and normalised data. 
Supplementary File SF3. Excel sheet: Summary of proteins detected bound to particles following 60 minute incubations. Raw data and normalised data.

Supplementary File SF4. Excel sheet: The BALF Proteome. Rank ordered by proteins identified in human bronchoalveolar lavage fluid. 


\section{Supplementary figures:}
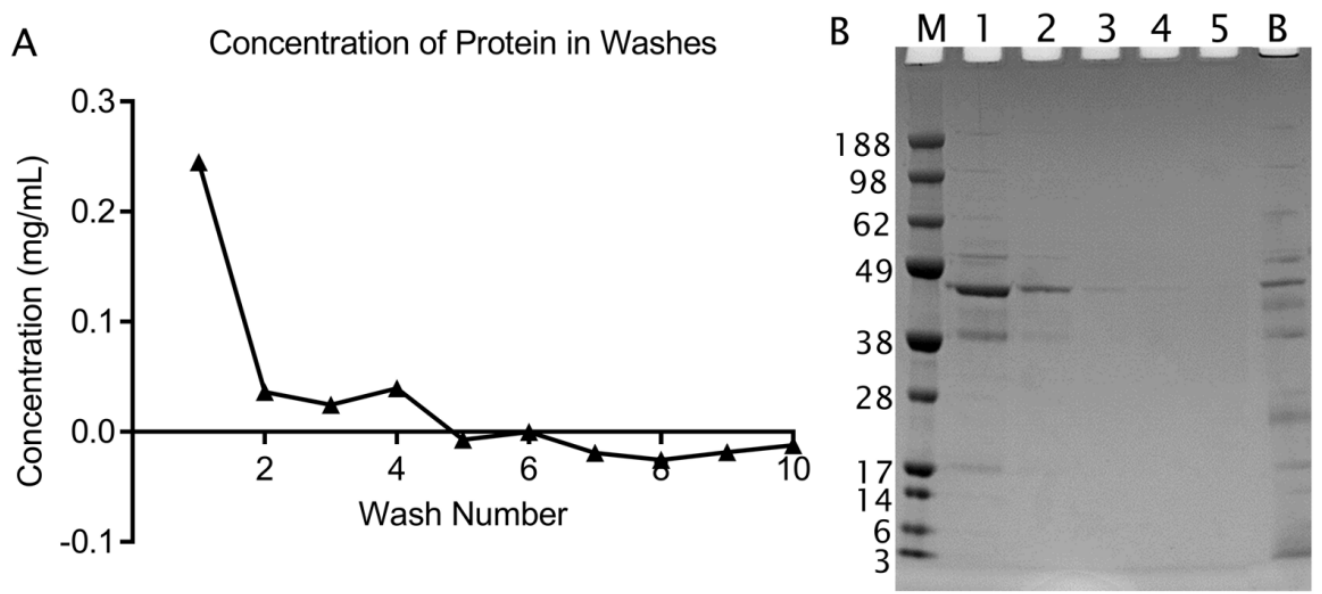

Supplementary figure S1: (A) The protein concentration in 10 consecutive washes was determined by BCA assay by washing in $200 \mu \mathrm{L}$ and using $12.5 \mu \mathrm{L}$ of each wash for BCA assay. The BCA analysis of the washes showed a sharp reduction in the bound proteins after 2 washes, dropping to subdetectable levels after 4 washes. (B) This was further corroborated by a SDS PAGE analysis using 10 $\mu \mathrm{L}$ of the first 5 washes and for the cPS particles. Therefore, 5 washes were performed on the particles prior to analysis of the corona in combination with increasing the wash volume to $1 \mathrm{~mL}$ per wash to ensure only bound proteins were left on the particles. $M=$ marker, with their respective $\mathrm{Mw}$ given $(\mathrm{kDa}) .1-5$ = washes. $\mathrm{B}=\mathrm{BALF}$ (for comparison).
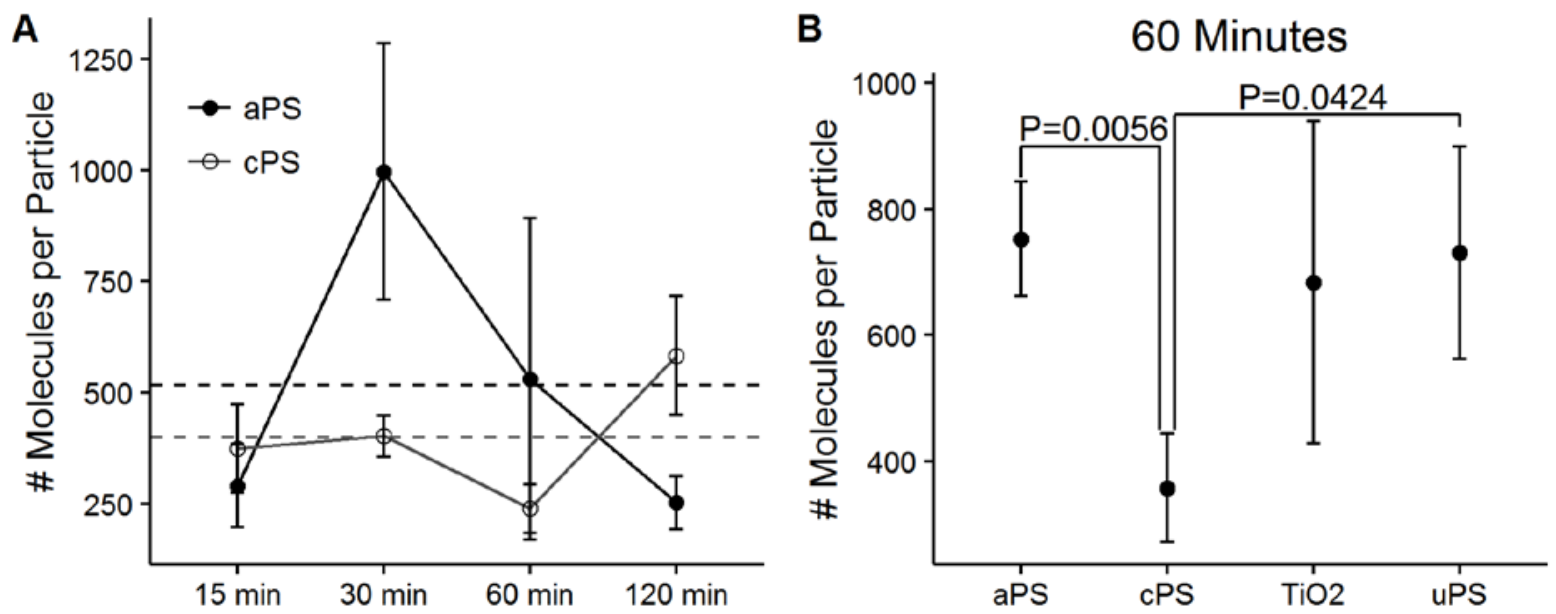

Supplementary figure S2: The number of protein molecules per particle, calculated from their size as determined hydrodynamic diameter for polystyrene and TEM for $\mathrm{TiO}_{2}$ particles. (A) Change in the number of proteins bound to aPS (grey line) and cPS (black line) over time. Dotted lines of the same colour represent the mean value across all time points. (B) The number of proteins molecules bound to each particle type after 60 minutes incubated (grey line, overall mean number of bound proteins). $\mathrm{P}$-values are given when $\mathrm{P}<0.05$ ( $\mathrm{T}$-Test). $\mathrm{N}=3$ independent experiments, mean \pm standard deviation. 